Check for updates

Cite this: Mater. Adv., 2021,

2, 1302

Received 13th December 2020,

Accepted 7th January 2021

DOI: $10.1039 / \mathrm{d} 0 \mathrm{ma00979b}$

rsc.li/materials-advances

\section{Nanoconfined growth of lithium-peroxide inside electrode pores: a noncatalytic strategy toward mitigating capacity-rechargeability trade-off in lithium-air batteries $\dagger$}

\begin{abstract}
Arghya Dutta, (D) *a Kimihiko Ito and Yoshimi Kubo*ab
Capacity-rechargeability trade-off in lithium-air batteries remains as one of the major challenges before their practical realization. As the discharge capacity increases, an uncontrolled growth of lithiumperoxide leads to passivation of the conductive electrode by a thick insulating layer that limits charge transport and results in a high overpotential during recharge. In contrast, deposition of lithium-peroxide inside a spatially confined electrode-space can restrict the growth and improve the rechargeability of the cell. The small crystallite size of spatially confined lithium-peroxide inside a porous framework is expected to show higher charge-transport that should play a crucial role in its facile decomposition. Here, a prototypical approach shows how a controlled increase in pore diameter, pore volume and electrochemically active surface area of a mesoporous carbon produces much higher discharge capacity by improving mass diffusion inside the mesoporous channels, yet simultaneously achieves an efficient rechargeability due to pore-confinement of lithium-peroxide.
\end{abstract}

\section{Introduction}

The highest theoretical specific energy of $3.5 \mathrm{~kW} \mathrm{~h} \mathrm{~kg}^{-1}$ makes lithium-air (Li-air) batteries one of the most promising future energy storage technologies for both stationary and mobile applications. Ideally, the overall electrochemical reaction in a nonaqueous $\mathrm{Li}$-air battery involves a two-electron $\left(2 \mathrm{e}^{-}\right)$redox of oxygen $\left(\mathrm{O}_{2}\right)$ in the presence of lithium $\left(\mathrm{Li}^{+}\right)$ions $\left(2 \mathrm{Li}^{+}+\mathrm{O}_{2}+2 \mathrm{e}^{-} \leftrightarrow\right.$ $\mathrm{Li}_{2} \mathrm{O}_{2}(\mathrm{~s}) ; E^{0}=2.96 \mathrm{~V}$ vs. $\mathrm{Li} / \mathrm{Li}^{+}$) leading to reversible formation (by the oxygen reduction reaction (ORR)) and decomposition (by the oxygen evolution reaction (OER)) of solid lithium peroxide $\left(\mathrm{Li}_{2} \mathrm{O}_{2}\right)$ during discharge (DC) and recharge (RC), respectively. ${ }^{1}$ However, passivation of the conducting electrode by this ostensibly insulating solid $\mathrm{Li}_{2} \mathrm{O}_{2}$ layer (both ionic and electronic conductivities in the range of $10^{-19}$ to $10^{-20} \mathrm{~S} \mathrm{~cm}^{-1}$ at $25{ }^{\circ} \mathrm{C}$ ) and diffusionlimitation of electroactive species in the electrode-pores result in lower than theoretically predicted capacity, poor rechargeability, low rate capability etc. ${ }^{2-5}$ Although an increase in carbon surface area as well as pore volume accessible to both $\mathrm{O}_{2}$ and electrolyte

\footnotetext{
${ }^{a}$ Center for Green Research on Energy and Environmental Materials, National Institute for Materials Science, 1-1 Namiki, Tsukuba 305-0044, Japan

${ }^{b}$ NIMS-SoftBank Advanced Technologies Development Center,

National Institute for Materials Science, 1-1 Namiki, Tsukuba 305-0044, Japan.

E-mail: dutta.arghya@nims.go.jp, kubo.yoshimi@nims.go.jp

$\dagger$ Electronic supplementary information (ESI) available: Experimental procedure, additional DC/RC curves, XRD, XPS, FTIR, SEM, LSV, OEMS, and impedance data. See DOI: 10.1039/d0ma00979b
}

could increase the DC capacity $\left(Q_{\mathrm{DC}}\right)$ of the cell, growth of large insulating crystals of $\mathrm{Li}_{2} \mathrm{O}_{2}$ with an increase in $Q_{D C}$ often led to deterioration of rechargeability as well as poor cyclability. ${ }^{6-8}$ The reason behind this low rechargeability is the limitation in charge transport through a thick $\mathrm{Li}_{2} \mathrm{O}_{2}$ layer that results in a high $\mathrm{RC}$ potential $>4 \mathrm{~V} v$ s. $\mathrm{Li} / \mathrm{Li}^{+}$and causes decomposition of both the nonaqueous electrolyte and carbon electrode. ${ }^{4,9,10}$ Worsening the situation, efforts to solve the rechargeability problem in Li-air batteries using solid electrocatalysts could not truly improve the ORR/OER reversibility. ${ }^{11,12}$ Rather, the use of these "catalysts" exacerbated electrolyte/electrode instabilities. Furthermore, the soluble redox-mediators also seemed to have (in)stability issues and their use on an unprotected anode led to passivation of the Li metal electrode. ${ }^{13,14}$ Therefore, it is necessary to identify a suitable noncatalytic strategy to increase the capacity without sacrificing the rechargeability of a Li-air battery.

Alternative to the usual uncontrolled growth of $\mathrm{Li}_{2} \mathrm{O}_{2}$ on widely used carbon nanotube (CNT) or carbon particle (Ketjen Black (KB), Super P (SP) etc.) based electrodes, confining the nucleation-and-growth of $\mathrm{Li}_{2} \mathrm{O}_{2}$ inside the framework-pores of a nanoporous carbon electrode can restrict the spatial growth of the discharge product below electron-tunnelling length and produce a nano-crystalline $\mathrm{Li}_{2} \mathrm{O}_{2}$ with small domain size. Compared to bulk crystalline $\mathrm{Li}_{2} \mathrm{O}_{2}$, this spatially confined poorly crystalline $\mathrm{Li}_{2} \mathrm{O}_{2}$ with a large interface with the carbon electrode is expected to show higher ionic and electronic conductivities that should suppress the recharge overpotential 
and help to achieve high round-trip energy efficiency in a Li-air battery. ${ }^{15,16}$ However, at the same time it is necessary to ensure facile mass-transport and enough space inside the porous framework to produce large $Q_{\mathrm{DC}}$ in the cell. Subsequently, as a result of improved mass and charge transport due to nanoconfinement of $\mathrm{Li}_{2} \mathrm{O}_{2}$ in an electrode with sufficient porosity, high rate-capability during both $\mathrm{DC}$ and $\mathrm{RC}$ of the cell can also be achieved. Based on this idea, herein, we first confirm that compared to the uncontrolled growth of $\mathrm{Li}_{2} \mathrm{O}_{2}$ on several commercial carbon electrodes, nanoconfinement of $\mathrm{Li}_{2} \mathrm{O}_{2}$ inside a mesoporous carbon results in a much higher roundtrip energy efficiency (ratio of energy densities during DC and $\mathrm{RC}$ respectively) that does not deteriorate with an increase in the depth of DC in a Li-air battery. Furthermore, we show that a controlled increase in the electrochemically active surface area (ECSA), pore diameter and pore volume of the mesoporous carbon electrode gradually enhances $Q_{\mathrm{DC}}$ by improving the diffusion of electroactive species inside the mesoporous channels and simultaneously maintains an efficient rechargeability in a $\mathrm{Li}-$ air battery due to the decomposition of nanocrystalline $\mathrm{Li}_{2} \mathrm{O}_{2}$ confined inside discrete pores of the electrode. It has been found that proper optimization of the physico-chemical properties of the carbon electrode could achieve $\sim 2.5$ times improvement in $Q_{\mathrm{DC}}$ but at the same time maintained an average $\mathrm{RC}$ potential of $\sim 3.6 \mathrm{~V} v s$. $\mathrm{Li} / \mathrm{Li}^{+}$which is 400 to $700 \mathrm{mV}$ lower than that of several other commercial carbon electrodes under similar conditions. This report demonstrates a prototypical strategy of a simple physico-chemical alteration in a porous carbon electrode as a metal-catalyst/promoter-free solution toward the capacityrechargeability trade-off in Li-air batteries.

\section{Results and discussion}

\section{Effect of pore-confinement of $\mathrm{Li}_{2} \mathrm{O}_{2}$ in $\mathrm{Li}$-air cells}

In order to verify the effect of pore-confined $\mathrm{Li}_{2} \mathrm{O}_{2}$ on suppressing $\mathrm{RC}$ overpotential $\left(\eta_{\mathrm{RC}}=\left|E^{0}-E_{\mathrm{RC}}\right|\right)$ we begin with comparing the DC/RC profiles of various carbon electrodes, such as CNT, KB, SP and mesoporous CMK-3, which have completely different surface morphologies and pore structures. While KB and SP carbons show particle-like morphology with 40-60 nm diameter, CNTs have tubular morphology with an average outer diameter of 20-40 $\mathrm{nm}$ and a length of 5-15 $\mu \mathrm{m}$. The morphologies of these carbons are shown by the scanning electron microscopic (SEM) images in Fig. S1(a) (ESI $\dagger$ ). Despite differences in morphologies, however, all these three commercial carbons give rise to inter-particle porosity with a random distribution of pore-space having diameter in the range of 50-100 nm. In contrast, CMK-3 with bead-like morphology has hexagonally ordered cylindrical mesopores $(<4 \mathrm{~nm}$ diameter $)$ aligned parallel to each other inside the carbon framework. ${ }^{17}$ Fig. S1(b) and (c) (ESI $\dagger$ ) respectively show nitrogen adsorption/desorption isotherms measured at $-196{ }^{\circ} \mathrm{C}$ and pore-size distribution by the BarrettJoyner-Halenda (BJH) method for different carbons. The pore structures are schematically presented in Fig. S1(d) (ESI $\dagger$ ). At first, $\mathrm{DC} / \mathrm{RC}$ of the cells was carried out in dry air (maximum dew point
$<-60{ }^{\circ} \mathrm{C}, \quad<11$ ppm (v/v) $\left.\mathrm{H}_{2} \mathrm{O}\right)$ using $1 \mathrm{M}$ lithium bis(trifluoromethanesulfonyl)imide (LiTFSI) in tetraethylene glycol dimethyl ether (TEGDME or tetraglyme; $<20$ ppm $\mathrm{H}_{2} \mathrm{O}$ ) as the electrolyte up to a limited $Q_{\mathrm{DC}}$ of $500 \mathrm{~mA} \mathrm{~h} \mathrm{~g}^{-1}$ at the same DC/RC current density $\left(j_{\mathrm{DC} / \mathrm{RC}}\right)$ of $100 \mathrm{~mA} \mathrm{~g}^{-1}$. The galvanostatic DC/RC profiles in Fig. 1(a) show quite similar DC potentials for all the electrodes, but significantly different RC potentials. Among these carbons, the mesoporous CMK-3 electrode shows the lowest average RC potential of $3.6 \mathrm{~V} v$ s. $\mathrm{Li} / \mathrm{Li}^{+}$, whereas the same for SP, $\mathrm{CNT}$ and $\mathrm{KB}$ are $4.28,4.17$ and $3.98 \mathrm{~V}$ vs. $\mathrm{Li} / \mathrm{Li}^{+}$respectively. Fig. 1(b) further shows that CMK-3 has the highest overall roundtrip energy efficiency of $74 \%$ which is $7-14 \%$ higher than those of the other carbons. During DC in the non-mesoporous carbons the inter-particle void spaces get filled with a thick film-like crystalline $\mathrm{Li}_{2} \mathrm{O}_{2}$ (>50 nm thick) that has very poor ionic as well as electronic conductivities and as a result, the decomposition of this insulating $\mathrm{Li}_{2} \mathrm{O}_{2}$ on these non-mesoporous carbons requires very high $\eta_{\mathrm{RC}}$ (usually, $\eta_{\mathrm{RC}}>1 \mathrm{~V}$ ). On the other side, the low $\eta_{\mathrm{RC}}$ in the CMK-3 electrode can certainly be corroborated to the facile decomposition of nanoconfined $\mathrm{Li}_{2} \mathrm{O}_{2}$ inside the mesoporous channels having an average pore diameter of $3.6 \mathrm{~nm}$ (see later).

The spatially restricted growth keeps the thickness of $\mathrm{Li}_{2} \mathrm{O}_{2}$ well below the electron tunneling limits $(\sim 10 \mathrm{~nm})$ and the small crystallite size results in much higher ionic conductivity compared to crystalline $\mathrm{Li}_{2} \mathrm{O}_{2} \cdot{ }^{2,15}$ Therefore, circumvention of charge-transport-limitation by nanoconfinement of $\mathrm{Li}_{2} \mathrm{O}_{2}$ should be a definite reason behind the suppression of $\eta_{\mathrm{RC}}$ in the CMK-3 electrode. The deposition of $\mathrm{Li}_{2} \mathrm{O}_{2}$ in these carbon electrodes is shown by the SEM images in Fig. S1(e) (ESI $\dagger$ ) and is schematically presented in Fig. 1(c-e). In order to verify the possibility of mass diffusion inside the mesoporous channels of CMK-3, we have precisely determined the hydrodynamic radii of the electroactive species in the electrolyte by using the Stokes-Einstein equation

$$
D=\frac{k_{\mathrm{B}} T}{6 \pi \mu r}
$$

where $D, k_{\mathrm{B}}, T, \mu$ and $r$ are the diffusion coefficient of the electroactive species, Boltzmann constant, temperature, viscosity of the electrolyte and hydrodynamic radius of the electroactive species in the electrolyte solution, respectively. The hydrodynamic radii of oxygen, $\mathrm{Li}^{+}$and $\mathrm{TFSI}^{-}$species in $1 \mathrm{M}$ LiTFSI/tetraglyme solution under an air atmosphere $(\sim 0.21$ bar $\mathrm{O}_{2}$ ) are calculated to be $\sim 1.2,0.41$ and $0.28 \mathrm{~nm}$, respectively, and detailed information with the values of all parameters used in this calculation is provided in the ESI. $\dagger$ These results confirm that the electroactive species can permeate through the porous channels of the CMK-3 electrode and take part in the electrochemical reactions inside the confined pore-space. However, it should be noted that although the hydrodynamic radii of the electroactive species are smaller than the radii of the mesopores in CMK-3 and additional capillary forces help $\mathrm{O}_{2}$ and electrolyte solution to diffuse into the mesoporous channels, the deposition of solid $\mathrm{Li}_{2} \mathrm{O}_{2}$ continuously decreases the porosity and blocks the diffusion channels during DC. ${ }^{18,19}$ As a result, the CMK-3 electrode shows much lower $Q_{\mathrm{DC}}\left(827 \mathrm{~mA} \mathrm{~h} \mathrm{~g}{ }^{-1}\right)$ than 
(a)

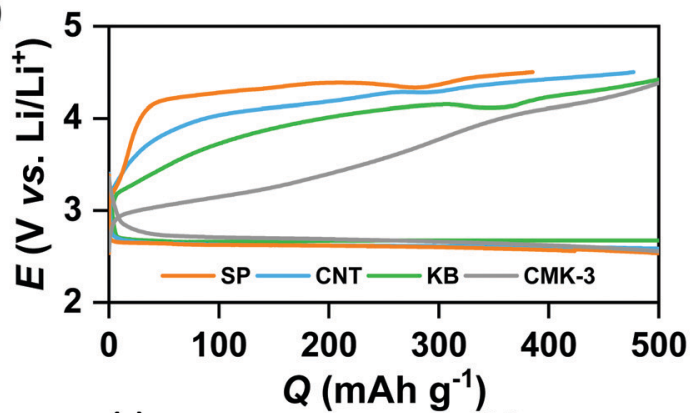

(b)

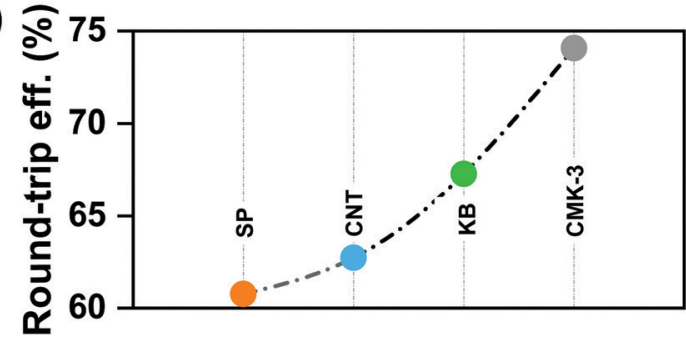

(d)

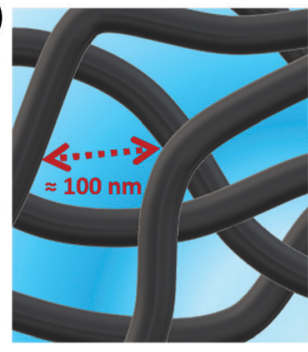

Deposition of $\mathrm{Li}_{2} \mathrm{O}_{2}$ inside interparticle pores of $\mathrm{KB}, \mathrm{SP}$ and CNT

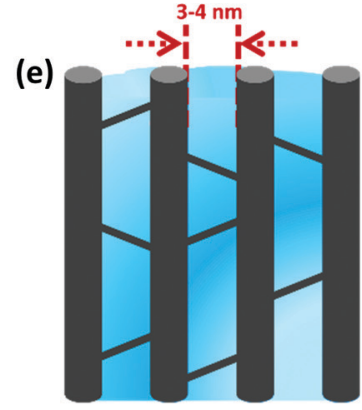

Deposition of $\mathrm{Li}_{2} \mathrm{O}_{2}$ inside mesopores of CMK-3

Fig. 1 (a) Galvanostatic discharge (DC)/recharge (RC) profiles of Li-air cells with different carbon electrodes in 1 M LiTFSI/tetraglyme electrolyte up to a fixed capacity of $500 \mathrm{~mA} \mathrm{~h} \mathrm{~g}^{-1}$ at the same current density of $100 \mathrm{~mA} \mathrm{~g}^{-1}$. (b) Comparison of round-trip efficiencies calculated from the ratio of energy densities during $D C$ and $\mathrm{RC}$ respectively for the $\mathrm{Li}$-air cells with different electrodes. Schematic representation of $\mathrm{Li}_{2} \mathrm{O}_{2}$ deposition (shown in blue) inside (c) KB/SP, (d) CNT and (e) CMK-3 electrodes.

that calculated $\left(1920 \mathrm{~mA} \mathrm{~h} \mathrm{~g}{ }^{-1}\right)$ from full utilization of the mesopore volume $\left(0.71 \mathrm{~cm}^{3} \mathrm{~g}^{-1}\right)$ (see later). Nonetheless, oxygen diffusion limitation is a general problem in air-electrodes, which are quite sensitive to the partial pressure of oxygen $\left(p_{\mathrm{O}_{2}}\right)$ in the feed gas. The effect of $p_{\mathrm{O}_{2}}$ on $Q_{\mathrm{DC}}$ of the electrodes was indeed observed when DC/RC of the cells was carried out in both dry air $\left(p_{\mathrm{O}_{2}}=0.21\right)$ and pure oxygen $\left(p_{\mathrm{O}_{2}}=1\right)$. Unsurprisingly, the $Q_{\mathrm{DC}}$ of the air-cells has been found to be much lower than that of the cells operated in pure oxygen. Fig. S2(a) and (b) (ESI $\dagger$ ) show the full DC/RC curves of the different carbons under pure oxygen and dry air respectively with the cut-off conditions of $2-4.5 \mathrm{~V} v s$. $\mathrm{Li} / \mathrm{Li}^{+}$at $j_{\mathrm{DC} / \mathrm{RC}}$ of $100 \mathrm{~mA} \mathrm{~g}^{-1}$. In Fig. S2(c) (ESI $\dagger$ ) we have shown a comparison between the $Q_{\mathrm{DC}}$ of oxygen and air cells for the respective carbon electrodes and a significantly lower $Q_{\mathrm{DC}}$, roughly in the range of $35-65 \%$, has been observed for all these carbons when air instead of oxygen is used as the feed gas. Nevertheless, practical applications of these batteries require operation in ambient air with simultaneously high energy and power densities as well as efficient rechargeability. Optimistically, the high rechargeability in the CMK-3 electrode is also maintained with $\sim 73 \%$ round-trip efficiency which is $6-13 \%$ higher than that of other carbons under an air atmosphere for a full DC up to $2 \mathrm{~V} v s$. $\mathrm{Li} / \mathrm{Li}^{+}$and the results are shown in Fig. S2(d) (ESI†). Owing to this high rechargeability, therefore, an efficient way has to be found out to further enhance the $Q_{\mathrm{DC}}$ of the mesoporous electrode toward mitigating the capacity-rechargeability trade-off in Li-air cells. In order to enhance the $Q_{\mathrm{DC}}$ of the mesoporous electrode, we adopted two different strategies: one of these was to induce solution mediated DC, while the other was to strategically modify the porosity of the carbon to enhance mass diffusion inside the porous framework.

Promoter assisted increase in $Q_{\mathrm{DC}}$ of the mesoporous electrode

Lithium nitrate $\left(\mathrm{LiNO}_{3}\right)$ and 2,5-di-tert-butyl-1,4-benzoquinone (DBBQ) were considered as the two promoters to induce solution mediated growth of $\mathrm{Li}_{2} \mathrm{O}_{2}$ and to increase the $Q_{\mathrm{DC}}$ of the CMK-3 electrode. ${ }^{20,21}$ Specifically, we used $1 \mathrm{M} \mathrm{LiNO}_{3}$ in tetraglyme and $1 \mathrm{M}$ LiTFSI $+50 \mathrm{mM}$ DBBQ in tetraglyme as the two electrolytes in Li-air cells. Fig. 2(a) shows the full DC/RC curves of CMK-3 electrodes in different electrolytes with or without promoters under dry air with the cut-off conditions of $2-4.5 \mathrm{~V} v s$. $\mathrm{Li}^{-\mathrm{Li}^{+}}$at $j_{\mathrm{DC} / \mathrm{RC}}$ of $100 \mathrm{~mA} \mathrm{~g}^{-1}$. It is indeed found that the use of $\mathrm{LiNO}_{3}$ and addition of DBBQ to LiTFSI as a promoter significantly increase the $Q_{\mathrm{DC}}$ of CMK-3 electrodes. A quantitative comparison of $Q_{\mathrm{DC}}$ in different electrolytes in Fig. 2(b) demonstrates that the $Q_{\mathrm{DC}}$ of CMK-3 increases from $827 \mathrm{~mA} \mathrm{~h} \mathrm{~g}{ }^{-1}$ in $1 \mathrm{M}$ LiTFSI to $1319 \mathrm{~mA} \mathrm{~h} \mathrm{~g}^{-1}$ in $1 \mathrm{M} \mathrm{LiNO}_{3}$ and $1863 \mathrm{~mA} \mathrm{~h} \mathrm{~g}^{-1}$ in $1 \mathrm{M} \mathrm{LiTFSI}+50 \mathrm{mM}$ DBBQ in tetraglyme electrolyte. However, this gain in $Q_{\mathrm{DC}}$ due to enhanced solution mediated deposition of $\mathrm{Li}_{2} \mathrm{O}_{2}$ is achieved at the cost of round-trip efficiency of the cells. From Fig. 2(b), the round-trip efficiency of $\sim 73 \%$ in $1 \mathrm{M}$ LiTFSI decreases to $\sim 67 \%$ in $1 \mathrm{M}$ $\mathrm{LiNO}_{3}$ and $\sim 50 \%$ in $1 \mathrm{M} \mathrm{LiTFSI}+50 \mathrm{mM}$ DBBQ in tetraglyme. The X-ray diffraction (XRD) patterns in Fig. S3(a) (ESI $\dagger$ ) confirm the formation of $\mathrm{Li}_{2} \mathrm{O}_{2}$ as the discharge product in all these three electrolytes and a detailed analysis of the XRD data in Fig. S3(b) (ESI $\dagger$ ) shows a slight increase in the domain size for the (100) reflection and an anisotropic growth of $\mathrm{Li}_{2} \mathrm{O}_{2}$ crystals with enhanced solution mediated DC of the CMK-3 electrode. 
(a)

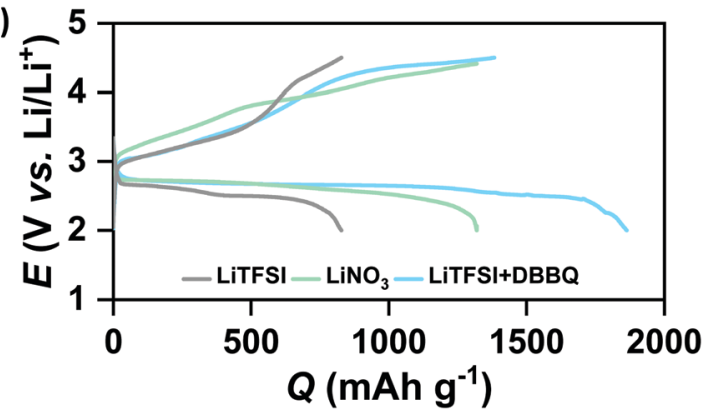

(b)

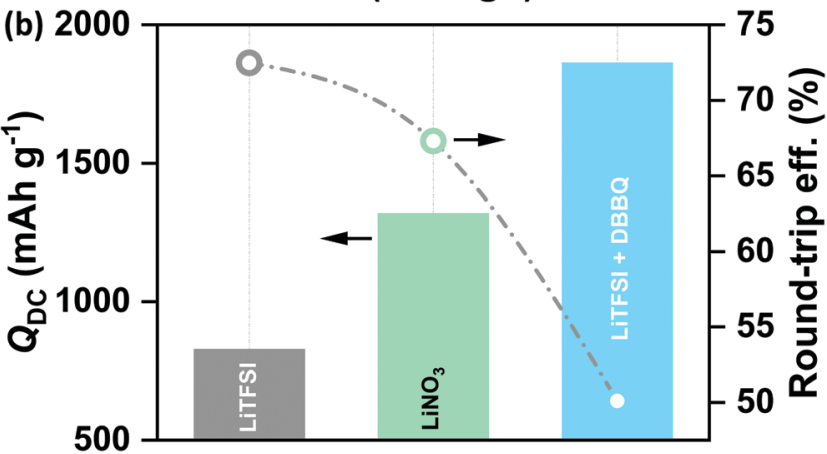

Fig. 2 (a) Galvanostatic DC/RC profiles of Li-air cells with a mesoporous CMK-3 electrode in different electrolytes and additives in the potential range of $2-4.5 \mathrm{~V} \mathrm{vs}$. Li/ $/ \mathrm{Li}^{+}$at the same current density of $100 \mathrm{~mA} \mathrm{~g}^{-1}$ and (b) comparison of DC capacity and round-trip efficiency of the cells in (a)

Since the occurrence of parasitic side reactions is thought to be a reason of poor rechargeability, we have also quantified the discharged $\mathrm{Li}_{2} \mathrm{O}_{2}$ by titration with TiOSO$_{4}$ solution. ${ }^{9}$ A much lower than $100 \%$ yield of $\mathrm{Li}_{2} \mathrm{O}_{2}$ after DC definitely indicates the occurrence of parasitic side reactions during DC. However, the $\mathrm{Li}_{2} \mathrm{O}_{2}$ yields of $71 \pm 2,74 \pm 1$ and $67 \pm 2 \%$ in $1 \mathrm{M} \mathrm{LiTFSI}, 1 \mathrm{M} \mathrm{LiNO}_{3}$ and 1 M LiTFSI + $50 \mathrm{mM}$ DBBQ respectively do not show any correlation with the rechargeability of the cells. Fig. S4 (ESI $\dagger$ ) shows the SEM images of the CMK-3 electrodes after full DC up to $2 \mathrm{~V}$ vs. $\mathrm{Li}^{-\mathrm{Li}^{+}}$at $100 \mathrm{~mA} \mathrm{~g}^{-1}$ in these three electrolytes. Much thicker $\mathrm{Li}_{2} \mathrm{O}_{2}$ layers on the outer surface of the electrode, owing to enhanced solution mediated deposition, have been observed after DC in $\mathrm{LiNO}_{3}$ and DBBQ containing electrolytes compared to LiTFSI alone. It is quite reasonable to imagine that inducing solution mediated ORR does not improve the access to the mesopores. Rather, solution phase growth of $\mathrm{Li}_{2} \mathrm{O}_{2}$ occurs in the inter-particle void spaces and the outer surface of the mesoporous carbon, which nullifies the benefits of mesopores in nanostructuring $\mathrm{Li}_{2} \mathrm{O}_{2}$ during DC. Therefore, the lower rechargeability of the cells in $\mathrm{LiNO}_{3}$ and DBBQ containing electrolytes can be attributed to a thicker $\mathrm{Li}_{2} \mathrm{O}_{2}$ layer with slightly larger crystallite size inhibiting facile charge-transfer during RC of the cells. ${ }^{22,23}$ As a result, a solution mediated increase in $Q_{\mathrm{DC}}$ in the CMK-3 electrode does not help to solve the capacity-rechargeability trade-off in $\mathrm{Li}-$ air batteries.

\section{Modification of mesoporous carbon for improved mass diffusion}

In contrast to promoter assisted uncontrolled growth of $\mathrm{Li}_{2} \mathrm{O}_{2}$, modification of the mesoporous carbon in terms of an increase in the pore diameter, pore volume, ECSA and number of ORR active sites should be a better alternative not only to improve mass diffusion inside the porous structure for higher $Q_{\mathrm{DC}}$ but also to maintain a controlled and restrictive growth of $\mathrm{Li}_{2} \mathrm{O}_{2}$ for facile decomposition during RC. Several experimental and theoretical studies have previously demonstrated the activities of N-doped carbons as efficient ORR catalysts that showed higher adsorption energies for both lithium and oxygen and facilitated the nucleation of $\mathrm{Li}_{2} \mathrm{O}_{2}$ on the electrode-surface. ${ }^{24-26}$ Furthermore, compared to precious metal ( $\mathrm{Pt}, \mathrm{Au}, \mathrm{Pd}$ and $\mathrm{Ru}$ ) and transition-metal oxide $\left(\mathrm{MnO}_{2}, \mathrm{Mn}_{3} \mathrm{O}_{4}, \mathrm{Co}_{3} \mathrm{O}_{4}\right.$ etc. $)$ catalysts, $\mathrm{N}$-doped carbons are attractive due to their low cost, high electronic conductivity and large surface area. Besides, several $\mathrm{N}$-doped mesoporous carbons were reported to possess bimodal porosity with larger mesopores that can improve mass diffusion during operation of Li-air cells. ${ }^{27,28}$ For these reasons, and due to relative ease of synthesis, we synthesized N-doped CMK-3 by a hard-templating route using phenol-urea-formaldehyde (PUF) precursor as the carbon source. By changing the concentration of urea, we synthesized four different N-doped CMK-3 carbons which are labelled as N-CMK-3-1 to -4 in the increasing order of N-content. The SEM images of the undoped and N-doped CMK-3 samples showing bulk morphologies and the corresponding elemental mapping by energy dispersive X-ray spectroscopy (EDS) identifying the surface chemical compositions are demonstrated in Fig. S5(a-e) (ESI $\dagger$ ). The SEM images show similar morphologies of the CMK-3 and N-CMK-3 samples, whereas the EDS mapping of the $\mathrm{N}$-doped samples confirms quite well dispersed doping of nitrogen in the carbon structure. In addition to nitrogen, high content of oxygen functionalities is also observed in all the carbon samples. In order to provide a quantitative idea about $\mathrm{N}$-doping and to precisely identify the $\mathrm{N}$ and O-functionalities, we carried out X-ray photoelectron spectroscopy (XPS) analyses of all the samples. The wide-scan, O1s, N1s and C1s XPS of all the carbon materials are shown in Fig. S6(a-d) (ESI $\dagger$ ) and the $\mathrm{N} / \mathrm{C}$ and $\mathrm{O} / \mathrm{C}$ values of all the samples are tabulated in Table 1. Deconvoluted N1s XPS show three characteristic peaks at $398.5 \pm 0.2,400.5 \pm 0.3$ and $403.8 \pm 0.3 \mathrm{eV}$, corresponding to pyridinic, pyrrolic and oxidized nitrogen, respectively, as shown in Fig. S6(c) (ESI $\dagger) .{ }^{27}$ The O1s and C1s XPS of all the samples in Fig. S6(b) and (d) (ESI $\dagger$ ), respectively, identify C-O (e.g., phenol, ether, epoxy etc. at $\mathrm{C} 1 \mathrm{~s} \sim 286.8 \pm 0.3 \mathrm{eV}$ and $\mathrm{O} 1 \mathrm{~s} \sim 532.5 \pm 0.1 \mathrm{eV}), \mathrm{C}=\mathrm{O}(e . g$., carbonyl, quinone etc. at C1s $287.7 \pm 0.3 \mathrm{eV}$ and $\mathrm{O} 1 \mathrm{~s} 530.5 \pm$ $0.2 \mathrm{eV}$ ) and $-\mathrm{COO}^{-}$(e.g., carboxylic acid, ester, lactone etc. at C1s $289.3 \mathrm{eV}$ ) groups to be present as the oxygen functionalities. ${ }^{29}$ The oxygens present in phenol, formaldehyde and urea are

Table 1 Physico-chemical properties of mesoporous carbons

\begin{tabular}{llllll}
\hline & $\mathrm{N} / \mathrm{C}$ & $\mathrm{O} / \mathrm{C}$ & $\begin{array}{l}S_{\mathrm{BET}} \\
\left(\mathrm{m}^{2} \mathrm{~g}^{-1}\right)\end{array}$ & $\begin{array}{l}V_{\mathrm{BJH}} \\
\left(\mathrm{cm}^{3} \mathrm{~g}^{-1}\right)\end{array}$ & $\begin{array}{l}\text { ECSA } \\
\left(\mathrm{m}^{2} \mathrm{~g}^{-1}\right)\end{array}$ \\
\hline CMK-3 & 0 & 0.093 & 1083 & 0.71 & 20.7 \\
N-CMK-3-1 & 0.029 & 0.072 & 1052 & 1.08 & 26.4 \\
N-CMK-3-2 & 0.032 & 0.091 & 1040 & 1.12 & 27.2 \\
N-CMK-3-3 & 0.04 & 0.087 & 1013 & 1.18 & 28.3 \\
N-CMK-3-4 & 0.051 & 0.09 & 898 & 1.12 & 23.9
\end{tabular}


thought to be the sources of these oxygen functionalities in the carbon. The specific surface area $\left(S_{\mathrm{BET}}\right)$ of all the samples was evaluated by the Brunauer-Emmett-Teller (BET) method from the $\mathrm{N}_{2}$ adsorption/desorption data obtained at $-196{ }^{\circ} \mathrm{C}$ and the pore structure was analyzed by the Barrett-Joyner-Halenda (BJH) method. The adsorption/desorption isotherms and $\mathrm{BJH}$ pore size distributions are shown in Fig. S7(a) and (b) (ESI $\dagger$ ) respectively and the corresponding values are summarized in Table 1 . In all cases the $\mathrm{N}_{2}$ adsorption/desorption shows a type IV isotherm which is the characteristic of a mesoporous material. ${ }^{30}$ In the case of CMK-3, a steep $\mathrm{N}_{2}$ adsorption (capillary condensation) takes place in the relative pressure $\left(P / P_{0}\right)$ range of 0.45-0.55, indicating the presence of high pore-size uniformity in the framework mesopores. ${ }^{31}$ The BJH pore size analysis also shows a narrow pore-size distribution with a sharp peak at $3.6 \mathrm{~nm}$. Similar type IV isotherms are observed for all the N-CMK-3 samples except that the capillary condensation takes place at higher $P / P_{0}(>0.6)$, which indicates the presence of larger mesopores since capillary condensation pressure is a function of pore diameter. ${ }^{30}$ Furthermore, the $\mathrm{H} 2(\mathrm{~b})$ hysteresis in the isotherms of N-CMK-3 samples evinces the presence of quite complex interconnected ink-bottle-shaped pore networks with a narrow distribution of pore bodies but a wide neck size distribution. ${ }^{32,33}$ From the BJH pore size analysis it is indeed found that the N-CMK-3 carbons show bimodal porosity and as the $\mathrm{N}$-content increases in the carbon framework, the pore diameter gradually increases and becomes more distributed. Since the samples were synthesized using mesoporous SBA-15 silica as the template, ideally the predominant pore diameter of all the samples should be very close to the wall thickness of SBA-15 $(\sim 4.5 \mathrm{~nm})$. But, due to the shrinkage of the pores in the carbon framework during carbonization of the precursor and templateremoval steps, the pore diameter $(3.6 \mathrm{~nm})$ of CMK-3 becomes lower than the pore wall thickness of the SBA-15 template. In contrast, the presence of larger mesopores (diameter $\sim 6 \mathrm{~nm}$ ) and ink-bottle-like cavities in the $\mathrm{N}$-doped carbons can be explained by the incomplete filling of PUF precursors inside the SBA-15 template during synthesis and partial decomposition of the PUF polymer during the carbonization process, leaving empty space in the carbon backbone. CMK-3 was synthesized by polymerization of the phenol-formaldehyde (PF) mixture and subsequent carbonization of the PF resin. In contrast, for the synthesis of N-CMK-3 samples the PUF precursor was used, where there are possibilities of several individual reactions, such as addition and condensation reactions of phenol, urea, and formaldehyde. ${ }^{34}$ Therefore, different self-condensation and co-condensation products can be formed during polymerization of the PUF precursor. This difference in the polymerization process can affect the filling level of the SBA-15 template and produce cavities in the resulting $\mathrm{N}$-doped carbons. Furthermore, addition of urea to PF resin results in poor bonding strength and lowers the stability of the resin that can decompose as well as shrink during the carbonization process. ${ }^{35}$ As a result, the N-CMK-3 samples show larger and more distributed mesopores than the CMK-3 carbon. Consequently, due to this enlargement of pore diameter and formation of interconnected framework cavities, the N-CMK-3 samples exhibit higher pore volume $\left(V_{\mathrm{BJH}}\right)$ and the values are shown in Table 1 . The mesoporous structure of the samples was visualized by transmission electron microscopy (TEM) images which, in Fig. 3(a-e), clearly demonstrate a hexagonally ordered mesopore arrangement for all the samples. Summarizing all these results, it is seen that N-doping of CMK-3 by addition of urea as a precursor not only increases the number of ORR active sites, but also successfully increases the porosity that can be further beneficial for Li-air battery operations. A schematic representation of the synthetic procedure of the mesoporous carbons is shown in Fig. 3(f).

\section{Discharge of N-CMK-3 electrodes in Li-air cells}

All the CMK-3 and N-CMK-3 electrodes were discharged and recharged in $1 \mathrm{M}$ LiTFSI/tetraglyme electrolyte $\left(<20 \mathrm{ppm}_{2} \mathrm{O}\right.$ ) under dry air with the cut-off condition of $2-4.5 \mathrm{~V} v s . \mathrm{Li} / \mathrm{Li}^{+}$at $j_{\text {DC/RC }}$ of $100 \mathrm{~mA} \mathrm{~g}^{-1}$. Fig. 4(a) shows the galvanostatic DC/RC curves of the undoped and doped CMK-3 electrodes. At a glance, the galvanostatic results demonstrate that $\mathrm{N}$-doping of

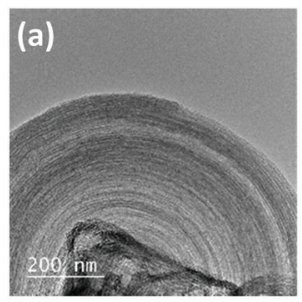

(f) Side view

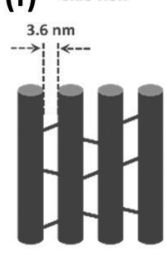

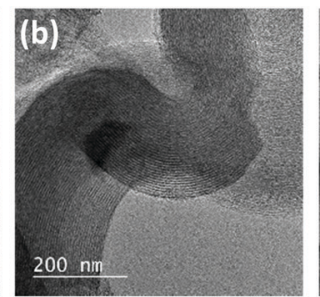
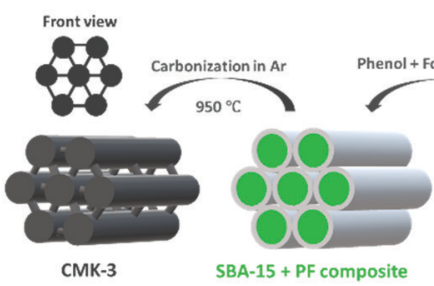

SBA-15 + PF composite
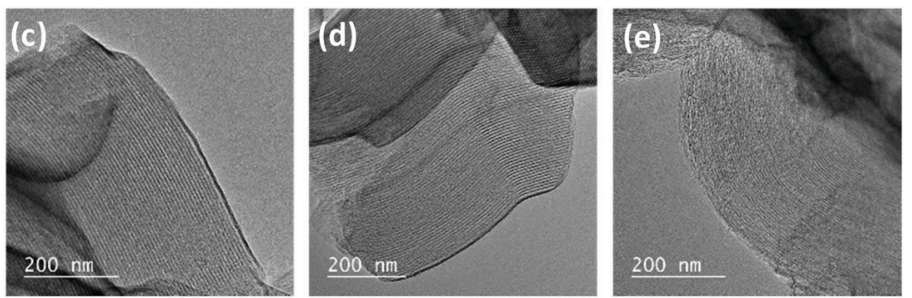

Side view

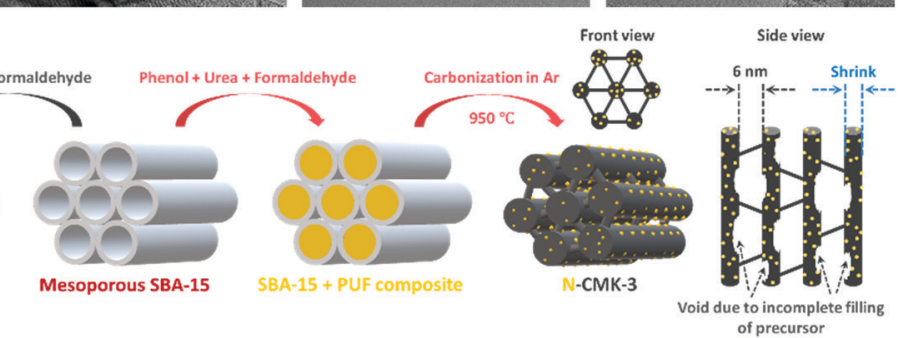

Fig. 3 Transmission electron microscopy (TEM) images of (a) CMK-3, (b) N-CMK-3-1, (c) N-CMK-3-2, (d) N-CMK-3-3 and (e) N-CMK-3-4. (f) Schematic representation of the synthetic steps for the mesoporous carbons. 
(a)

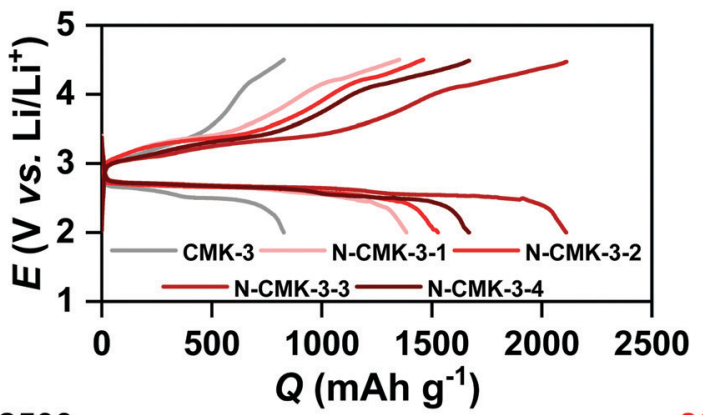

(b) 2500
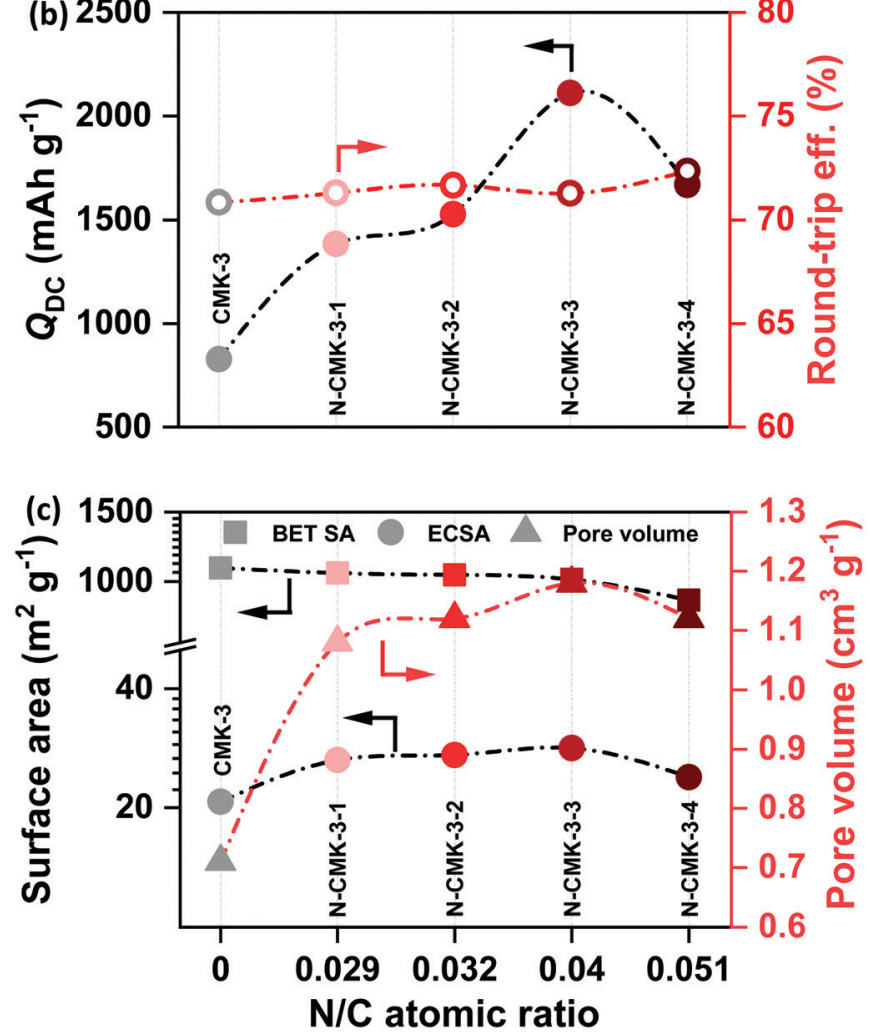

(d)

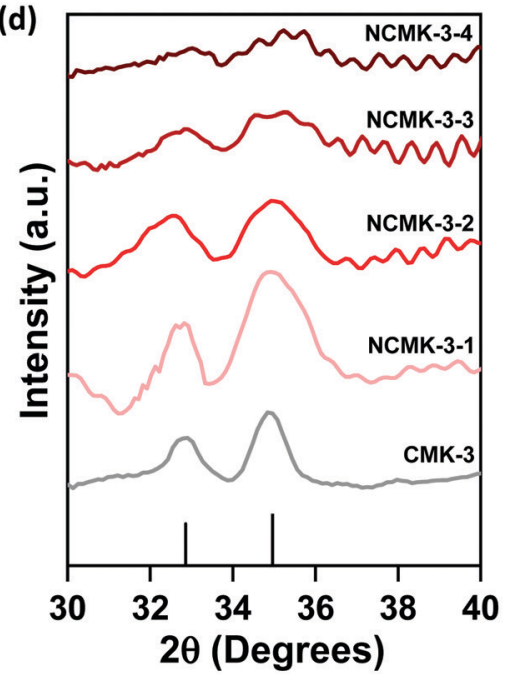

(e)

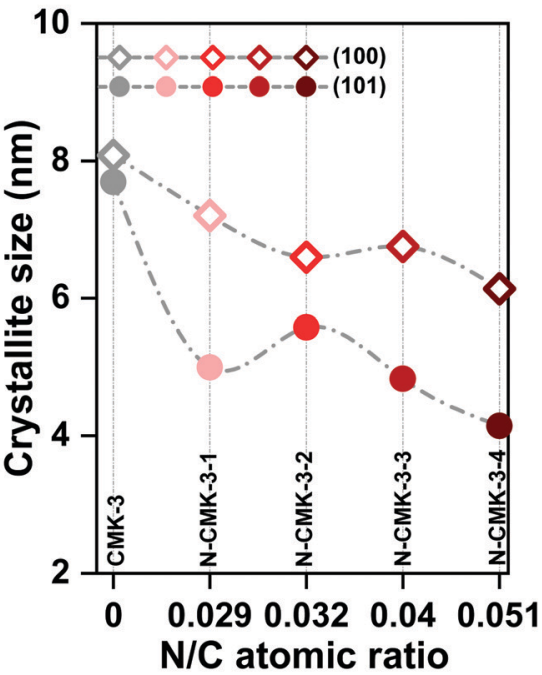

Fig. 4 (a) Galvanostatic DC/RC profiles of Li-air cells with mesoporous CMK-3 and N-CMK-3 electrodes in $1 \mathrm{M}$ LiTFSI/tetraglyme in the potential range of 2-4.5 V vs. Li/Li at the same current density of $100 \mathrm{~mA} \mathrm{~g}^{-1}$, (b) comparison of DC capacity and round-trip efficiency of the cells in (a), (c) comparison of Brunauer-Emmett-Teller (BET) surface area, electrochemically active surface area (ECSA) and pore volume of the mesoporous carbons, (d) X-ray diffraction (XRD) patterns of the discharged mesoporous electrodes and (e) comparison of lithium-peroxide $\left(\mathrm{Li}_{2} \mathrm{O}_{2}\right)$ crystallite size in different mesoporous electrodes.

CMK-3 significantly increases the $Q_{\mathrm{DC}}$ of the cells. From the quantitative comparison of $Q_{\mathrm{DC}}$ of doped and undoped CMK-3 electrodes in Fig. 4(b) it is found that with an increase in the $\mathrm{N} / \mathrm{C}$ atomic ratio, the $Q_{\mathrm{DC}}$ of the mesoporous carbon gradually increases from $827 \mathrm{~mA} \mathrm{~h} \mathrm{~g}^{-1}$ in $\mathrm{CMK}-3(\mathrm{~N} / \mathrm{C}=0)$ to 1385 $(\mathrm{N}-\mathrm{CMK}-3-1, \mathrm{~N} / \mathrm{C}=0.029), 1528(\mathrm{~N}-\mathrm{CMK}-3-2, \mathrm{~N} / \mathrm{C}=0.032)$ and $2111 \mathrm{~mA} \mathrm{~h} \mathrm{~g}^{-1}(\mathrm{~N}-\mathrm{CMK}-3-3, \mathrm{~N} / \mathrm{C}=0.04)$ before decreasing to $1668 \mathrm{~mA} \mathrm{~h} \mathrm{~g}^{-1}$ in N-CMK-3-4 (N/C = 0.051). Interestingly, the values of $Q_{\mathrm{DC}}$ do not follow the trend of the N/C ratio and the peak of $Q_{\mathrm{DC}}$ at $2111 \mathrm{~mA} \mathrm{~h} \mathrm{~g}{ }^{-1}$ for N-CMK-3-3 and then a decrease in the value to $1668 \mathrm{~mA} \mathrm{~h} \mathrm{~g}^{-1}$ for N-CMK-3-4 certainly indicate that an increase in concentration of nitrogen as the ORR active sites is not the sole reason for capacity enhancement in these N-doped CMK-3 electrodes. In order to understand the reason behind the increase in $Q_{\mathrm{DC}}$ upon N-doping of the CMK-3 electrode, we thoroughly analyzed the pore structures of these carbon materials. Fig. 4(c) shows a decreasing trend of the $S_{\mathrm{BET}}$ with an increase in the N/C ratio. Surprisingly this observation is contradictory to the trend of $Q_{\mathrm{DC}}$ for these electrodes because intuitively, capacity should be proportional to the surface area of the electrodes. Nonetheless, the pore size and pore volume of these carbons seem consistent with $Q_{\mathrm{DC}}$ values.

An increase in the pore diameter from 3.7 to $\sim 6 \mathrm{~nm}$ is certainly expected to enhance mass transport inside the N-CMK-3 electrodes compared to undoped CMK-3. Furthermore, as shown in Fig. 4(c), with an increase in the N/C atomic ratio, the pore volume gradually increases, reaches a peak for N-CMK-3-3 (1.18 $\mathrm{cm}^{3} \mathrm{~g}^{-1}, \mathrm{~N} / \mathrm{C}$ of 0.04$)$ with $\sim 66 \%$ enhancement from the undoped one $\left(0.71 \mathrm{~cm}^{3} \mathrm{~g}^{-1}, \mathrm{~N} / \mathrm{C}\right.$ of 0$)$ and then 
decreases for the N-CMK-3-4 (1.12 $\mathrm{cm}^{3} \mathrm{~g}^{-1}, \mathrm{~N} / \mathrm{C}$ of 0.051$)$ electrode. As mentioned earlier, during synthesis of these carbons, different filling levels of the pores of the SBA-15 template by the precursors and partial decomposition of PUF resin with relatively low mechanical strength result in higher pore volume in N-CMK-3 samples than in the undoped CMK-3. However, too high fraction of urea for the synthesis of N-CMK3-4 (urea to phenol ratio of 1:0.6) might have lowered the mechanical strength of the precursor resin excessively and possible occurrence of several self and co-condensation reactions producing small fragments instead of a continuous polymeric network could lead to partial collapse of the carbon framework during carbonization. ${ }^{34}$ As a result, N-CMK-3-4 breaks the increasing trend of pore volume with the N/C ratio and shows smaller pore volume than N-CMK-3-3. Since ECSA provides a more precise estimate of the electrode-area available for electrochemical reactions, we measured and plotted the ECSA (see the $\mathrm{ESI} \dagger$ for detailed calculation) of these mesoporous carbons in Fig. 4(c). Interestingly, the ECSA values do not follow the trend of $S_{\mathrm{BET}}$, rather show a similar trend of pore volume and correlate with the observed $Q_{\mathrm{DC}}$ of the electrodes. This correlation can be attributed to enhanced penetration of electroactive species inside the mesoporous framework as the pore diameter and pore volume of the carbon increase. After DC of the cells in air the discharged electrodes were thoroughly analyzed by XPS, infra-red spectroscopy (FTIR) and XRD to identify the predominant DC products. Fig. S8(a and b) (ESI $\dagger$ ) show XPS of discharged CMK-3 and N-CMK-3-3 electrodes, respectively. The single component Li1s spectra at $\sim 55 \mathrm{eV}$ and O1s spectra at $\sim 532 \mathrm{eV}$ confirm the deposition of $\mathrm{Li}_{2} \mathrm{O}_{2}$ as the major DC product. ${ }^{36}$ Besides, the O1s spectra show additional peaks at $>532 \mathrm{eV}$ that can be assigned to $-\mathrm{CO}_{3},-\mathrm{CO}$ or $\mathrm{SO}_{2}$ species resulting from parasitic reactions or adsorbed electrolyte residues on the deposited $\mathrm{Li}_{2} \mathrm{O}_{2}$ and additionally multiple components in the deconvoluted C1s spectra also indicate the presence of several functionalities, such as $\mathrm{C}-\mathrm{C}, \mathrm{CH}_{x}, \mathrm{CO}_{x}$ etc., in the discharged electrodes. ${ }^{36}$ Consistent with the XPS results, the FTIR spectra of the discharged CMK-3 and N-CMK-3 electrodes in Fig. S9 (ESI $\dagger$ ) identify $\mathrm{Li}_{2} \mathrm{CO}_{3}$ and $\mathrm{Li}$-carboxylates to be the parasitic products during DC. There can be different ways for the formation of parasitic side products in $\mathrm{Li}$-air cells where, in addition to electrolyte and electrode decomposition, the $\mathrm{CO}_{2}(0.04 \%)$ present in air can also undergo electrochemical reaction during DC to directly produce $\mathrm{Li}_{2} \mathrm{CO}_{3}$ as an undesired product. ${ }^{37,38}$ Nevertheless, the parasitic side reaction between the carbon electrode and the nonaqueous electrolyte with a superoxide intermediate is a persistent problem in a $\mathrm{Li}$-air battery that demands more stable electrolytes and electrode materials. ${ }^{9,10}$ Fig. 4(d) and Fig. S10 (ESI $\dagger$ ) show the XRD patterns of the discharged CMK-3 and N-CMK-3 electrodes. These XRD patterns not only confirm $\mathrm{Li}_{2} \mathrm{O}_{2}$ as the DC product in these electrodes, but also show a significant decrease in peak intensity at a high $\mathrm{N} / \mathrm{C}$ ratio in the $\mathrm{N}$-doped carbons. This means lower fractions of crystalline $\mathrm{Li}_{2} \mathrm{O}_{2}$ are deposited as the $\mathrm{N} / \mathrm{C}$ ratio increases. Besides, a gradual broadening of both (100) and (101) reflections of $\mathrm{Li}_{2} \mathrm{O}_{2}$ is observed with an increase in the N/C ratio. The broadening of the XRD peaks indicates a decrease in the average $\mathrm{Li}_{2} \mathrm{O}_{2}$ crystallite-size which is plotted in Fig. 4(e) for all the samples. It is found that the respective crystallite size for the (100) and (101) reflections of $\mathrm{Li}_{2} \mathrm{O}_{2}$ decreases from $\sim 8$ and $7.7 \mathrm{~nm}$ in CMK-3 to $\sim 6.1$ and $4.1 \mathrm{~nm}$ in N-CMK-3-4. Unlike unrestricted growth of $\mathrm{Li}_{2} \mathrm{O}_{2}$ crystals in conventional carbons without framework-porosity, here in the case of these mesoporous carbons the initial nucleation takes place inside a confined porous channel that restricts the spatial growth of $\mathrm{Li}_{2} \mathrm{O}_{2}$. As shown earlier in this article, the hydrodynamic radii of the electroactive species are much smaller than that of the mesopores in these $\mathrm{N}$-doped carbons. Furthermore, the interconnected ink-bottle pores in $\mathrm{N}-\mathrm{CMK}-3$ electrodes are expected to show more facile mass transport along the mesoporous channels. Once diffuse into the pores, these electroactive species get confined inside the nanoscopic space where heterogeneous interaction between the reactants and the electrode surface is tremendously amplified. ${ }^{39}$ Consequently, very high interfacial area inside the mesopores significantly enhances the kinetics of the electrochemical reactions. Moreover, the turbostratic structure with considerable defects and N/O-doping enhance the ORR activity in these mesoporous CMK-3 based materials compared to other commercial carbons. ${ }^{26,40}$ We have compared the ORR activities of all the CMK-3 and N-CMK-3 electrodes by cathodic linear sweep voltammetry (LSV) in the range of 3.2 to $2 \mathrm{~V} v s$. $\mathrm{Li} / \mathrm{Li}^{+}$at a sweep rate of $0.5 \mathrm{mV} \mathrm{s}^{-1}$ using metallic $\mathrm{Li}$ as both the counter and reference electrodes. Apparently, the integrated areas under the LSV curves in Fig. S11(a) (ESI $\dagger$ ) depicting the amount of charge passed for the ORR show a similar trend of $Q_{\mathrm{DC}}$ observed in galvanostatic DC. Fig. S11(b) (ESI $\dagger$ ) shows the current densities $\left(j_{\text {ORR }}\right)$ of all these electrodes at three different potentials of $2.8,2.7$ and $2.6 \mathrm{~V} v s$. $\mathrm{Li} / \mathrm{Li}^{+}$during $\mathrm{LSV}$ scan, where overall a gradual increase in ORR current response has been observed with an increase in the N/C ratio in the N-CMK-3 electrodes. We have also identified the overpotential $(\eta=|2.96-E|, \mathrm{V})$ required to reach the $j_{\text {ORR }}$ of $0.05,0.1$ and $0.15 \mathrm{~mA} \mathrm{~cm}^{-2}$ in all these undoped and $\mathrm{N}$-doped CMK-3 electrodes and the results in Fig. S11(c) (ESI $\dagger$ ) consistently show that with an increase in the $\mathrm{N} / \mathrm{C}$ ratio the overpotential to reach respective $j_{\text {ORR }}$ becomes lower. Furthermore, the Tafel plots in Fig. S11(d) (ESI $\dagger$ ) yield Tafel slopes of 473, 370, 383, 373 and 443 $\mathrm{mV} \mathrm{dec}{ }^{-1}$ for CMK-3 and N-CMK-3-1 to -4 electrodes respectively and these values unequivocally demonstrate an enhancement in ORR activities of the N-CMK-3 electrodes compared to the undoped one. As a result of this good electrocatalytic activity, the strong interaction between depositing $\mathrm{Li}_{2} \mathrm{O}_{2}$ and the surface of the $\mathrm{N}$-doped electrode leads to growth of a poorly crystalline thinfilm-like $\mathrm{Li}_{2} \mathrm{O}_{2}$ on the surface of the carbons, even outside of the porous framework (SEM in Fig. S12, ESI $\dagger$ ). ${ }^{41}$ Therefore, despite higher $Q_{\mathrm{DC}}$ in N-CMK-3 electrodes, owing to the structural effect of the porous framework as well as the electrocatalytic activities of the $\mathrm{N}$-sites, the size of individual $\mathrm{Li}_{2} \mathrm{O}_{2}$ crystallites remains small.

\section{Recharge of N-CMK-3 electrodes in $\mathrm{Li}$-air cells}

It is important to note from Fig. 4(a) and (b) that the increase in $Q_{\mathrm{DC}}$ in the case of N-CMK-3 electrodes does not affect the rechargeability and overall round-trip efficiency of the cells. The average RC potential for all the CMK-3 and N-CMK-3 
electrodes has been calculated to be $<3.65 \mathrm{~V} v s . \mathrm{Li} / \mathrm{Li}^{+}$and Fig. 4(b) shows that $>70 \%$ round-trip efficiency is maintained in all the $\mathrm{N}$-doped electrodes despite up to $\sim 2.5$ times increase in $Q_{\mathrm{DC}}$ during full $\mathrm{DC} / \mathrm{RC}$ in air. These results demonstrate a successful mitigation of capacity-rechargeability trade-off in Li-air battery. A closer look at the galvanostatic curves reveals that the RC at these electrodes starts at potentials very close to $3 \mathrm{~V}$ vs. $\mathrm{Li} / \mathrm{Li}^{+}$, remains below $3.5 \mathrm{~V}$ vs. $\mathrm{Li} / \mathrm{Li}^{+}$up to $50 \%$ state of charge (SOC) and goes above $4 \mathrm{~V}$ vs. $\mathrm{Li}^{-\mathrm{Li}^{+}}$at $70-75 \%$ SOC. Online electrochemical mass spectrometry (OEMS) of N-CMK-33 as the representative electrode shows the trend of gas evolution during $\mathrm{RC}$ of a cell with $\mathrm{N}$-doped mesoporous carbon. Correlating the RC curve of N-CMK-3-3 in Fig. 5(a) with OEMS data in Fig. 5(b) it is found that $\mathrm{O}_{2}$ gas starts evolving as soon as $\mathrm{RC}$ of the cell begins and the onset of $\mathrm{O}_{2}$ evolution is very close to $3 \mathrm{~V} v s$. $\mathrm{Li} / \mathrm{Li}^{+}$. The gas evolution trend further shows that as the RC progresses, a copious amount of $\mathrm{O}_{2}$ is evolved below $3.5 \mathrm{~V}$ vs. $\mathrm{Li} / \mathrm{Li}^{+}$. These observations give direct evidence of a facile decomposition of $\mathrm{Li}_{2} \mathrm{O}_{2}$ below $3.5 \mathrm{~V} v s . \mathrm{Li} / \mathrm{Li}^{+}$in the case of the N-CMK-3-3 electrode. However, a gradual increase in RC potential and a large amount of carbon dioxide $\left(\mathrm{CO}_{2}\right)$ evolution at the later part of $\mathrm{RC}\left(>4 \mathrm{~V} v s . \mathrm{Li} / \mathrm{Li}^{+}\right)$indicate decomposition of deposited parasitic side products, such as lithium carbonate and lithium carboxylate, as evidenced by XPS and FTIR observations. Nevertheless, when compared with OEMS data of the CNT electrode in Fig. S13(a) and (b) (ESI $\dagger$ ), this mesoporous N-CMK-3-3 electrode shows much better $\mathrm{O}_{2}$ evolution efficiency and a lower amount of evolved $\mathrm{CO}_{2}$. In the CNT electrode, the onset potential for $\mathrm{O}_{2}$ evolution is $>3.5 \mathrm{~V}$ vs. $\mathrm{Li} / \mathrm{Li}^{+}$and a significant flux of $\mathrm{O}_{2}$ is achieved only at potentials $>4 \mathrm{~V} v s$. $\mathrm{Li} / \mathrm{Li}^{+}$. These comparative results definitely confirm the efficiency of $\mathrm{N}$-doped mesoporous carbons for the facile decomposition of

(a)

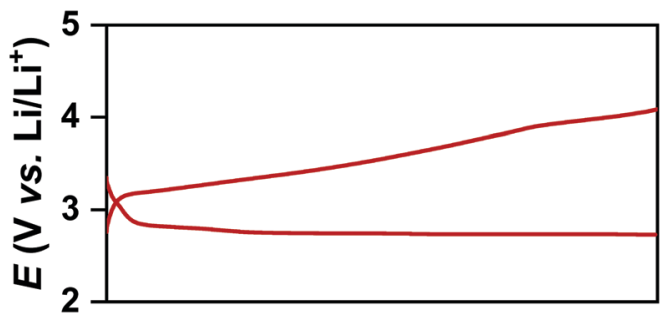

(b)

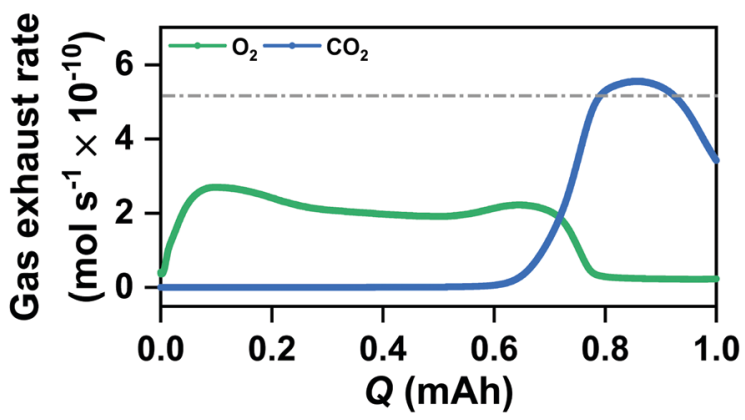

Fig. 5 (a) Galvanostatic DC/RC profiles of the mesoporous N-CMK-3-3 electrode in $1 \mathrm{M} \mathrm{LiTFSI/tetraglyme} \mathrm{electrolyte} \mathrm{up} \mathrm{to} \mathrm{a} \mathrm{fixed} \mathrm{capacity} \mathrm{of}$ $1 \mathrm{mAh}$ at $100 \mathrm{~mA} \mathrm{~g}^{-1}$ and (b) corresponding in situ gas evolution data during recharge of the cell.
$\mathrm{Li}_{2} \mathrm{O}_{2}$ during $\mathrm{RC}$ of the cell. Interestingly, the efficacy of $\mathrm{O}_{2}$ evolution by the decomposition of $\mathrm{Li}_{2} \mathrm{O}_{2}$ seems quite similar for N-CMK-3-3 and CMK-3 electrodes, as shown in Fig. S14(a) and (b) (ESI $\dagger$ ). These similarly efficient $\mathrm{O}_{2}$ evolution efficiencies of N-CMK-3-3 and CMK-3 electrodes reaffirm the role of mesopores for the facile decomposition of $\mathrm{Li}_{2} \mathrm{O}_{2}$. However, at the same time it indicates no additional contribution from N-sites as an OER catalyst during $\mathrm{RC}$ of the $\mathrm{Li}$-air cells. In order to ascertain OER catalytic activity trend with the N/C ratio, we have carried out anodic LSV $\left(0.05 \mathrm{mV} \mathrm{s}^{-1}\right)$ of these electrodes after reduction up to $Q_{\mathrm{DC}}$ of $0.5 \mathrm{~mA} \mathrm{~h} \mathrm{~cm} \mathrm{~cm}^{-2}$ as shown in Fig. S15(a) (ESI $\dagger$ ) that exhibits two pronounced oxidation peaks, one centered around $3.4 \mathrm{~V}$ vs. $\mathrm{Li} / \mathrm{Li}^{+}$and another above $4 \mathrm{~V}$ vs. $\mathrm{Li} / \mathrm{Li}^{+}$. In order to compare the OER activities of these electrodes, we have analyzed the LSV curves in the $\eta_{\mathrm{RC}}$ range below $250 \mathrm{mV}$. The onset potentials for the OER of all the mesoporous electrodes are found to be quite similar and close to $3 \mathrm{~V} v s$. $\mathrm{Li} / \mathrm{Li}^{+}$. However, interestingly, the current responses at different overpotentials (see Fig. S15(b), ESI $\dagger$ ) and vice versa (see Fig. S15(c), ESI $\dagger$ ) do not show any correlation with the N/C ratio. Therefore, the direct role of N-sites in catalyzing the OER cannot be confirmed in these electrodes. Rather, these results evince the predominant effect of nanoconfined $\mathrm{Li}_{2} \mathrm{O}_{2}$ in suppressing $\eta_{\mathrm{RC}}$ of the cells. Although $\mathrm{Li}_{2} \mathrm{O}_{2}$ is thought to be a wide-bandgap insulator (band gaps of 5-6.4 eV), electrochemically formed $\mathrm{Li}_{2} \mathrm{O}_{2}$ usually possesses several defect sites that act as the charge carriers and improve the overall conductivity. ${ }^{4}$ Specifically, in the case of mesoporous electrodes, nanocrystalline $\mathrm{Li}_{2} \mathrm{O}_{2}$ with a large number of defectrich interfaces and grain boundaries may play a significant role in enhancing the charge carrier dynamics that should benefit a facile decomposition during RC of the cells. ${ }^{15,22}$ Moreover, according to density functional theory (DFT) calculations, cohesive interactions of $\mathrm{Li}$ and $\mathrm{O}_{2}$ with carbon surfaces during nucleation of $\mathrm{Li}_{2} \mathrm{O}_{2}$ lead to electron transfer from the anti-bonding $\mathrm{O}_{2}$ orbitals to the carbon electrode and induce a p-type conductivity at the $\mathrm{Li}_{2} \mathrm{O}_{2}$ /electrode interface. ${ }^{42}$ As a result of the strong interaction with carbon, the $\mathrm{Li}-\mathrm{O}$ bond length in the nucleating $\mathrm{Li}_{2} \mathrm{O}_{2}$ may also elongate and diminish the interaction between $\mathrm{Li}$ and $\mathrm{O}$ atoms resulting in higher mobility of $\mathrm{Li}^{+}$in the $\mathrm{Li}_{2} \mathrm{O}_{2}$ crystal. ${ }^{41}$ A comparative impedance analysis of discharged KB and N-CMK3-3 electrodes in Fig. S16 (ESI $\dagger$ ) indeed shows more facile charge transport for the latter electrode and supports the hypothesis presented in this work. In the case of $\mathrm{N}$ and O-doped carbons, the electron-withdrawing hetero atoms can activate neighboring $\mathrm{C}$ atoms for stronger adsorption of $\mathrm{Li}$ and $\mathrm{O}_{2}$ and induce deposition of disordered or poorly-crystalline $\mathrm{Li}_{2} \mathrm{O}_{2}$ as the discharged product, which is consistent with the XRD results in Fig. 4(d) and (e). ${ }^{43}$ A prior DFT calculation showed that during DC of the cell the binding of depositing $\mathrm{Li}_{2} \mathrm{O}_{2}$ units on top of the initially nucleated disordered $\mathrm{Li}_{2} \mathrm{O}_{2}$ layer becomes weak with a lower than expected coordination number and continues building up a disordered structure. ${ }^{16}$ Therefore, in the cases of N-CMK-3 electrodes depositions of the poorly crystalline $\mathrm{Li}_{2} \mathrm{O}_{2}$ having weaker bonding, a lower coordination number and improved ionic/electronic conductivities continue despite an increase in $Q_{\mathrm{DC}}$ and maintain low $\eta_{\mathrm{RC}}$ during $\mathrm{RC}$ of the cells. 
Comparison of rate capabilities of different electrodes in $\mathrm{Li}$-air cells

Retention of high $Q_{\mathrm{DC}}$ together with low $\eta_{\mathrm{RC}}$ at high current densities is significantly important for the development of practical Li-air batteries. Fig. S17(a)-(d) (ESI $\dagger$ ) respectively show the galvanostatic DC/RC curves of Li-air cells with N-CMK-3-3, KB, CNT and SP electrodes at different $j_{\mathrm{DC} / \mathrm{RC}}$ from 100 to $500 \mathrm{~mA} \mathrm{~g}^{-1}$. From these DC/RC curves, we have calculated and compared the gravimetric energy and power densities of these electrodes during DC and the results are shown by the Ragone plots in Fig. 6(a). Expectedly, all the electrodes show an apparent anticorrelation between gravimetric energy and power capabilities due to charge transport as well as oxygen diffusion limitations at high $j_{\text {DC }}$. Build-up of an insulating $\mathrm{Li}_{2} \mathrm{O}_{2}$ layer during DC increases the electronic resistivity of the carbon electrode and at the same time blocks the oxygen diffusion paths resulting in lower $Q_{\mathrm{DC}}$ at higher $j_{\mathrm{DC}} \cdot{ }^{2,5}$ Nonetheless, among these carbon electrodes, N-CMK-3-3 and KB show much better retention of gravimetric energy at high power compared to the other two electrodes. Higher surface area (both $S_{\mathrm{BET}}$ and ECSA) and pore volume of N-CMK-3-3 and KB than those of CNT and SP can be attributed to this higher energy and power capabilities. Therefore, consistent with a previous report, high

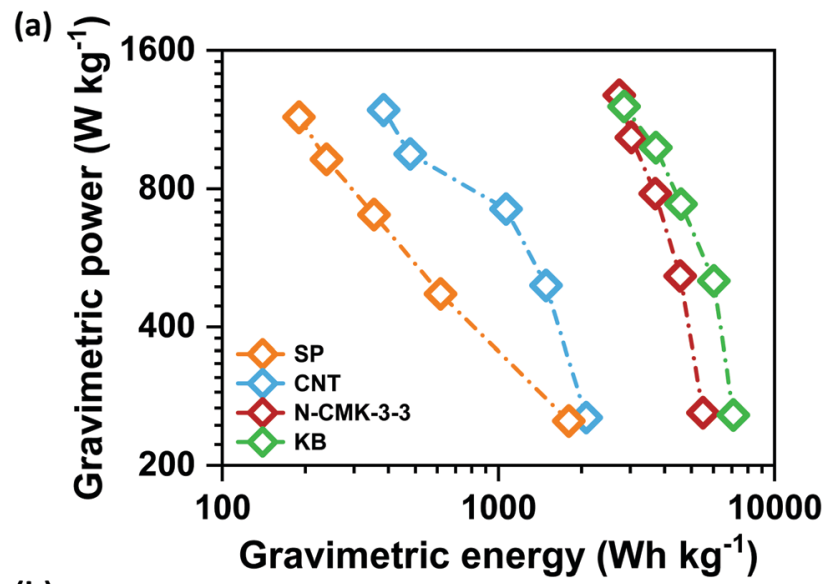

(b)

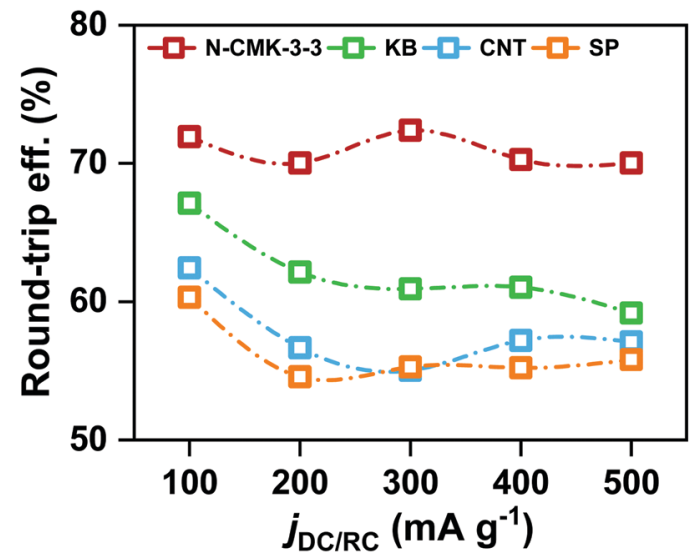

Fig. 6 (a) Ragone plot for Li-air cells with different electrodes in $1 \mathrm{M}$ LiTFSI/tetraglyme and (b) round-trip efficiencies of the Li-air cells cycled in $1 \mathrm{M} \mathrm{LiTFSI} /$ tetraglyme in the potential range of $2-4.5 \mathrm{~V} \mathrm{vs}$. $\mathrm{Li}^{\prime} / \mathrm{Li}^{+}$at different current densities. surface area and large pore volume in a carbon electrode seem to be essential requirements to achieve simultaneously high energy and power densities during DC of a Li-air battery. ${ }^{5}$ However, Fig. 6(b) shows that the trend of DC performances in these electrodes does not correlate with the rechargeability of the cell. Considering rechargeability, the performance of N-CMK-3-3 profoundly stands out from the other three electrodes. The N-CMK-3-3 electrode consistently maintains a round-trip energy efficiency of $>70 \%$ at high $j_{\text {DC }}$ up to $500 \mathrm{~mA} \mathrm{~g}^{-1}$, which is $\mathbf{5}-\mathbf{1 5 \%}$ higher than those of $\mathrm{KB}$, CNT and SP. This significantly higher rechargeability of the N-CMK-3-3 electrode at a high rate can again be ascribed to the formation of spatially restricted poorly crystalline $\mathrm{Li}_{2} \mathrm{O}_{2}$ with better $\mathrm{Li}^{+}$mobilities that can transport charges more rapidly than bulk crystalline $\mathrm{Li}_{2} \mathrm{O}_{2}$ formed in other electrodes. ${ }^{15}$ These results indicate that high surface area and large pore volume coupled with a mesoporous framework help the N-CMK-3-3 electrode to produce high capacity with efficient rechargeability even at high current rates during both DC and RC, respectively. The efficient rechargeability of the N-CMK-3-3 electrode was tested over repeated cycles and was also compared with the cyclability of the $\mathrm{KB}$ electrode under same conditions and the results are shown in Fig. S18 (ESI $\dagger$ ). The cycling data further show better performance for the N-CMK-3-3 electrode in suppressing the $\eta_{\mathrm{RC}}$ over several cycles. However, deterioration in cycling stability is evident for both these electrodes and this can be attributed to parasitic side reactions as explained before.

\section{Conclusions}

In summary, we have successfully demonstrated a noncatalytic strategy to improve the discharge capacity of a Li-air battery without sacrificing the rechargeability and overall energy efficiency of the cell. To do so, we have chosen mesoporous carbon as the electrode material that offers a confined pore-space for spatially restricted growth of $\mathrm{Li}_{2} \mathrm{O}_{2}$. Unlike the uncontrolled growth of $\mathrm{Li}_{2} \mathrm{O}_{2}$ in conventional high surface area electrodes, the confined growth inside the mesopores produces nanostructured $\mathrm{Li}_{2} \mathrm{O}_{2}$ that is benefited with high mobility of $\mathrm{Li}^{+}$ and other charge carriers for facile decomposition during recharge. We have further shown that a controlled increase in electrochemically active surface area, pore width and pore volume of the carbon, while maintaining the mesoporous framework, can significantly enhance the discharge capacity and at the same time retain high rechargeability. In our study, we followed a wet chemical pathway for the synthesis of mesoporous carbons using mesoporous silica as the hard template that was impregnated with a phenol-formaldehyde mixture with or without urea as the carbon precursor. Our results have shown that addition of urea not only introduces nitrogen as a dopant in the carbon skeleton but also increases the porosity in the framework. For a certain dopant concentration, the porosity reaches a maximum and the electrode produces a discharge capacity that is nearly 2.5 times higher than that of the undoped carbon. Interestingly, despite this 
significant increase in discharge capacity, the electrode still maintains a round-trip energy efficiency of $>70 \%$ which is up to $15 \%$ higher than that in the conventional electrodes. Detailed investigations have found that, although enhanced porosity accommodates a larger amount of $\mathrm{Li}_{2} \mathrm{O}_{2}$ and gives higher discharge capacity, the mesoporous framework in the $\mathrm{N}$-doped carbons produces spatially restricted nano-sized and poorly crystalline $\mathrm{Li}_{2} \mathrm{O}_{2}$ that decomposes at low recharge potential. Our study demonstrates a prototypical strategy of electrode modification for the controlled growth of $\mathrm{Li}_{2} \mathrm{O}_{2}$ in order to achieve high capacity with simultaneously high rechargeability and provides crucial insights into electrode design for future development of efficient Li-air batteries.

\section{Author contributions}

A. D. conceived the research, synthesized the materials, carried out the electrochemical measurements and wrote the manuscript. K. I. carried out the OEMS experiments and Y. K. supervised the overall research and contributed to scientific discussions and writing of the manuscript.

\section{Conflicts of interest}

The authors declare no conflict of interest.

\section{Acknowledgements}

This work was financially supported by JST ALCA-SPRING Grant Number JPMJAL1301, Japan. The authors thank Battery Research Platform for experimental facilities.

\section{Notes and references}

1 P. G. Bruce, S. A. Freunberger, L. J. Hardwick and J.-M. Tarascon, Nat. Mater., 2012, 11, 19-29.

2 V. Viswanathan, K. S. Thygesen, J. S. Hummelshøj, J. K. Nørskov, G. Girishkumar, B. D. McCloskey and A. C. Luntz, J. Chem. Phys., 2011, 135, 214704.

3 O. Gerbig, R. Merkle and J. Maier, Adv. Mater., 2013, 25, 3129-3133.

4 M. D. Radin and D. J. Siegel, Energy Environ. Sci., 2013, 6, 2370-2379.

5 A. Dutta, K. Ito and Y. Kubo, J. Mater. Chem. A, 2019, 7, 23199-23207.

6 S. Meini, M. Piana, H. Beyer, J. Schwämmlein and H. A. Gasteiger, J. Electrochem. Soc., 2012, 159, A2135-A2142.

7 W. Pan, X. Yang, J. Bao and M. Wang, J. Electrochem. Soc., 2017, 164, E3499-E3511.

8 C. Xia, M. Waletzko, L. Chen, K. Peppler, P. J. Klar and J. Janek, ACS Appl. Mater. Interfaces, 2014, 6, 12083-12092.

9 B. D. McCloskey, D. S. Bethune, R. M. Shelby, T. Mori, R. Scheffler, A. Speidel, M. Sherwood and A. C. Luntz, J. Phys. Chem. Lett., 2012, 3, 3043-3047.
10 M. M. Ottakam Thotiyl, S. A. Freunberger, Z. Peng and P. G. Bruce, J. Am. Chem. Soc., 2013, 135, 494-500.

11 R. A. Wong, C. Yang, A. Dutta, M. O. M. Hong, M. L. Thomas, K. Yamanaka, T. Ohta, K. Waki and H. R. Byon, ACS Energy Lett., 2018, 3, 592-597.

12 B. D. McCloskey, R. Scheffler, A. Speidel, D. S. Bethune, R. M. Shelby and A. C. Luntz, J. Am. Chem. Soc., 2011, 133, 18038-18041.

13 W.-J. Kwak, J. Park, H. Kim, J. M. Joo, D. Aurbach, H. R. Byon and Y.-K. Sun, ACS Energy Lett., 2020, 5, 2122-2129.

14 Y. Lin, C. Martinez-Martinez, J.-W. Kim and J. W. Connell, J. Electrochem. Soc., 2020, 167, 080522.

15 F. Tian, M. D. Radin and D. J. Siegel, Chem. Mater., 2014, 26, 2952-2959.

16 A. Dutta, R. A. Wong, W. Park, K. Yamanaka, T. Ohta, Y. Jung and H. R. Byon, Nat. Commun., 2018, 9, 680.

17 S. Jun, S. H. Joo, R. Ryoo, M. Kruk, M. Jaroniec, Z. Liu, T. Ohsuna and O. Terasaki, J. Am. Chem. Soc., 2000, 122, 10712-10713.

18 M. Choi and R. Ryoo, Nat. Mater., 2003, 2, 473-476.

19 V. Y. Nimon, S. J. Visco, L. C. De Jonghe, Y. M. Volfkovich and D. A. Bograchev, ECS Electrochem. Lett., 2013, 2, A33-A35.

20 X. Gao, Y. Chen, L. Johnson and P. G. Bruce, Nat. Mater., 2016, 15, 882-888.

21 C. M. Burke, V. Pande, A. Khetan, V. Viswanathan and B. D. McCloskey, Proc. Natl. Acad. Sci. U. S. A., 2015, 112, 9293.

22 A. Dunst, V. Epp, I. Hanzu, S. A. Freunberger and M. Wilkening, Energy Environ. Sci., 2014, 7, 2739-2752.

23 Y. Yin, C. Gaya, A. Torayev, V. Thangavel and A. A. Franco, J. Phys. Chem. Lett., 2016, 7, 3897-3902.

24 Z. Zhang, J. Bao, C. He, Y. Chen, J. Wei and Z. Zhou, Adv. Funct. Mater., 2014, 24, 6826-6833.

25 J. Shui, F. Du, C. Xue, Q. Li and L. Dai, ACS Nano, 2014, 8, 3015-3022.

26 Y. Jing and Z. Zhou, ACS Catal., 2015, 5, 4309-4317.

27 T. Lin, I. W. Chen, F. Liu, C. Yang, H. Bi, F. Xu and F. Huang, Science, 2015, 350, 1508.

28 S. N. Talapaneni, S. Anandan, G. P. Mane, C. Anand, D. S. Dhawale, S. Varghese, A. Mano, T. Mori and A. Vinu, J. Mater. Chem., 2012, 22, 9831-9840.

29 Z. R. Yue, W. Jiang, L. Wang, S. D. Gardner and C. U. Pittman, Carbon, 1999, 37, 1785-1796.

30 M. Kruk and M. Jaroniec, Chem. Mater., 2001, 13, 3169-3183.

31 D. D. Asouhidou, K. S. Triantafyllidis, N. K. Lazaridis, K. A. Matis, S.-S. Kim and T. J. Pinnavaia, Microporous Mesoporous Mater., 2009, 117, 257-267.

32 A. Grosman and C. Ortega, Langmuir, 2008, 24, 3977-3986. 33 Y. Zeng, C. Fan, D. D. Do and D. Nicholson, Ind. Eng. Chem. Res., 2014, 53, 15467-15474.

34 D.-B. Fan, G.-Y. Li, T.-F. Qin and F.-X. Chu, Polymers, 2014, 6, 2221-2231.

35 B. Pang, M.-K. Li, S. Yang, T.-Q. Yuan, G.-B. Du and R.-C. Sun, ACS Omega, 2018, 3, 8521-8528. 
36 A. Guéguen, P. Novák and E. J. Berg, J. Electrochem. Soc., 2016, 163, A2545-A2550.

37 D. Geng, N. Ding, T. S. A. Hor, S. W. Chien, Z. Liu, D. Wuu, X. Sun and Y. Zong, Adv. Energy Mater., 2016, 6, 1502164.

38 H.-K. Lim, H.-D. Lim, K.-Y. Park, D.-H. Seo, H. Gwon, J. Hong, W. A. Goddard, H. Kim and K. Kang, J. Am. Chem. Soc., 2013, 135, 9733-9742.

39 J. H. Bae, J.-H. Han and T. D. Chung, Phys. Chem. Chem. Phys., 2012, 14, 448-463.
40 R. A. Wong, A. Dutta, C. Yang, K. Yamanaka, T. Ohta, A. Nakao, K. Waki and H. R. Byon, Chem. Mater., 2016, 28, 8006-8015.

41 Y. Yang, T. Zhang, X. Wang, L. Chen, N. Wu, W. Liu, H. Lu, L. Xiao, L. Fu and L. Zhuang, ACS Appl. Mater. Interfaces, 2016, 8, 21350-21357.

42 Y. Zhao, C. Ban, J. Kang, S. Santhanagopalan, G.-H. Kim, S.-H. Wei and A. C. Dillon, Appl. Phys. Lett., 2012, 101, 023903. 43 A. Dutta, K. Ito, A. Nomura and Y. Kubo, Adv. Sci., 2020, 7, 2001660. 